Z 4705 ；莫大な IEC 規格との整合のため，昨年度の審 議が今年度に持ち越され, JIS 改正案が第 2 回の本委員 会に提案されたが，時間切れで第 3 回の本委員会で審議 されることとなった。第 3 回は平成 5 年 2 月に開催され る.

(橋本 宏)

\section{患者用 X線防護衣（歯科用）班}

1）班編成のいきさつ：「JIS Z 4830 患者用X線防護衣」 は新しいJIS 規格で1990年から検討され，1992年に制定 された。

この規格の目的は患者が体外から受ける散乱線による 生殖腺の防護にあり，スカートとエプロンについてのみ 規定している.この規格の審議中, 特に問題になったの は歯科用防護衣の取扱いであったが歯科という特殊な分 野であるし，IECの規格案でも取上げていないこともあ り規格の対象から除外された経緯があった.（JISの解説 から)

しかし，使用頻度が多く甲状腺被曝の多い歯科用防謢 衣については，次回の改正時に規格化の対象として検討 する事となっている。

このために，班を編成し改正に備えて検討する事とな った.

2）歯科専用の防護衣は必要か？；1992年11月に各自文 献をもちより首記の件に関し，最初の検討会を行なった。 その結果, X線口内法撮影時には唾液腺, 甲状腺, 水晶 体，胸部などの被曝量が多く，散乱線だけでなく多少の 直接線も関与しており，さらに子供の撮影も多いため, パノラマ撮影用も含めて歯科専用の防護衣の必要性を確 認した。

3）歯科領域における防護の現状と今後の対策：鉛当量, 形状とも一定のものはなく，また，甲状腺防護について も衿つき, ネックガード式, ベルト式などこちらもバラ バラである.

現在, 29の歯科大学, 歯学部附属病院には, 約 100 人の 診療放射線技師が勤務しており，歯科における防護の垁 際と JIS 化に際しての鉛当量, 防護衣の形状などについ て，アンケート調查を行なう事となった。（田中 守）

\section{JIS Z 4705 (医用電子加速装置) 改正 見直し委員会班}

昨年度から引き続き改正作業を行った１985年に IEC 601-2-1 "Safty of medical electrical equipment" part 1: General, part 2: Particular requirements for medical electrical electron accelerators in the range $1 \mathrm{Mev}$ to $50 \mathrm{Mev}$ の和訳を元にして, JIS Z 4705 が作られた. 旧規格には総則と放射線安全のみで, “機械的安全”, “電 気的安全”が含まれず, 試験法も不備であったため今回 は大幅な改正となった。

改正された規格は IEC 601-2-1（1981）と, その後発 行されたIEC 601-2-1 Amendment 1 (1984) 及び Amendment 2 (1990) を元にして翻訳し, JIS 形式に書 き換えた. 更に近年はコンピュータ又はマイクロプロセ ッサを用いた加速装置が普及したため, 諸外国では安全 対策の不備による事故も報告されており，IEC（CO） 61 (1990) に追加されたのでこの文書の一部を追加採用 した. 昨年度は主に翻訳作業をおこないJIS の項目に合 わせた。

今年度は JIS Z 4705 改正分科会委員から郵送により 原案に対するコメントを戴き，特別対策委員会で文章の 修正と形式を JIS に適合させる作業を行った。会議は 9 回開催された。本文，附属書で50頁を越えるボリューム となった１0月の JIS 本委員会で原案が了承されたた め, 一部文章の修正をおこない, 工技院規格調整委員会 に提出する運びとなった。発行は平成 5 年 8 月頃の予定. 旧規稒との大きな違いの一つは放射線安全の試験は附 属書 2 で試験の種類, 試験区分及び手順又は原理につい て詳細に記述されている事である。試験法の概要の一例 を示す.

《試験の種類》 形式試験

受渡試験

《試験区分》

A 法：放射線安全に関連して製造者が提供する加速装 置の設計解析に対する調査.

B 法：加速装置の外観調査，機能試験又は測定．試験 手順は附属書 2 の規定により，加速装置の回路又は構造 に手を加えずに得られる作動状態（故障状態を含む。）だ けに基づいている。

C 法：加速装置の機能試験又は測定. 試験原理は附属 書 2 の規定による．製造業者は，その原理に基づく試験 手順を附属文畫に記載すること，試験手順には，加速装 置の回路又は構造に手を加える必要のある作動状態を含 んでもよい. 《手順》又は《原理》

主な構成と項目を以下に示す。

日本工業規格（案）

医用電子加速装置-安全

JIS Z 4705 (199X)

Requirments for the safety of medical electron accel- 
erators
1. 適用範团
2. 用語の定義
3. 加速装置の分類
4. 構造
5. 性能
6. 試験方法の概要
7. 試験方法
8. 表示
9. 附属文書
10. 取扱い上の注意事項

○附属書 1 不要又は過剰な放射線に対する防護

○附属書 2 不要又は過剩な放射線に対する防護に関す る試験方法

○解説

(平林久枝)

\section{JIS Z 4721 医用 X線イメージインテンシ ファイア改正見直し委員会班}

この規格は1982年に制定され，1987年に IEC との整合 を目的とした改正があった．今年はその見直しを行ない， 改正原案を作成した。

現行 JIS には,

1）入射面視野寸法の計算

2）輝度分布の測定

3）変換係数の測定

4）像ひずみの測定

が IEC 規格に整合して規定されている.しかし, 現在最 も重要な性能であるコントラスト比と解像度の測定は IECで規格されていないため含まれていない.

今回の改正原案は従来規定された部分については根本 的改正はなく，コントラスト比および解像度の測定につ いて, 日本放射線機器工業会規格 JESRA X-57「医用X 線イメージインテンシファイアのコントラスト比の測 定」およびX-58「医用X線イメージインテンシファイア の測定」を参照して追加した。 その要点は以下のと扔り である。

コントラスト比の测定

X線ビーム

- 焦点と入射面の距離は, $1000 \pm 10 \mathrm{~mm}$ とする.

・X線管電圧は, $50 \mathrm{kV}$ 一定として, 吸収体なしとする. 試験片

○入射面までの距離は, $10 \mathrm{~mm}$ 以下とする.

・試験片の種類は次の二種類ある.

(a) $10 \%$ 面積コントラスト比用（鉛 $2 \mathrm{~mm}$ 厚以上） (b) $10 \mathrm{~mm}$ 直径コントラスト比用（鉛 $2 \mathrm{~mm}$ 厚以上） 测定と計算

・試験片を置いたときと除去したときの出力像中心輝度 を測定し，その比を求める.

解像度の测定

$\mathrm{X}$ 線ビーム

- 焦点と入射面の距離は, $1000 \pm 10 \mathrm{~mm}$ とする.

- X線管焦点は, $0.3 \mathrm{~mm}$ 以下とする.

- X線管電圧は，40〜 $50 \mathrm{kV}$ として，吸収体なしとする. 試験片

-入射面までの距離は, $10 \mathrm{~mm}$ 以下とする.

・JIS Z 4916 に規定されたチャートを用いる。ただし， このチャートではステップが粗すぎる場合には，板厚が 鉛当量で50 $\mu \mathrm{m} \sim 100 \mu \mathrm{m}$ の細かいパターンのチャート を用いてもよい。

測定

- 出力面での試験片の像を, 光学的に拡大して肉眼視に より测定する。

(細矢志郎)

\section{環境 $\gamma$ 線連続モニ夕等 JIS 改正原案 作成委員会班}

当初の見直しテーマは JIS Z 4330 (放射性水モ二タ) の予定だった。しかし今年度はIEC の動き等に照らし見 直し JIS 数が多過ぎるため,この JIS は最終的に他の班 が行うこととなった。この班の作業と並行し今年度は, JIS Z 4325（環境 $\gamma$ 線連続モ二夕）・Z 4326 (環境 $\gamma$ 線 連続モニタの校正方法) $・ Z 4314$ (X線及び $\gamma$ 線用蛍光ガ ラス線量計測装置）の3規格を見直し，Z4326（校正方 法）については “Z 4325 （連続モニ夕）の附属書”へと 変更し答申した.

1. 環境 $\gamma$ 線連続モニ夕

(1) 本 文

このモニタにはシンチレーション式と電離箱式の $2 つ$ の型式があり, 刘象線量は $\mathrm{Gy} \cdot \mathrm{h}^{-1}$ 単位で表示される $\gamma$ 線の空気吸収線量率となる. 性能に関しては, (1)指示誤 差・(2)エネルギー特性・(3)方向特性・(4)指示值変動・ (5) ドリフト・(6)オーバスケール特性・(7)警報レベルの誤差・ (8)温度特性・ (9)耐雨性・(10)電源電圧の変動に対する安定 性, の10項目が盛り込まれ，試験並びに形式検査はこれ ら10項目全部に対し実施済みでなければならない。また 前記の性能と試験項目のうち，(2)のエネルギー特性に対 しては校正用基準線源を特定し, 核種は, ${ }^{57} \mathrm{Co}(124 \mathrm{KeV} /$ 271.65 日） ${ }^{60} \mathrm{Co}\left(1250 \mathrm{KeV} / 5.27\right.$ 年) ${ }^{133} \mathrm{Ba}(340 \mathrm{KeV} /$ 10.66 年) $\cdot{ }^{137} \mathrm{Cs}\left(660 \mathrm{keV} / 30.17\right.$ 年) ${ }^{226} \mathrm{Ra}(780 \mathrm{KeV} /$ 